\title{
In vitro shoot proliferation and development of micropropagation protocol from leaf disc of Gladiolus
}

\author{
M. Shaheenuzzaman ${ }^{1}$, M. S. Haque ${ }^{2}$, M. M. Karim ${ }^{1}$ and Z. U. Noor ${ }^{3}$ \\ ${ }^{1}$ Agronomy Division, BARI, Gazipur, ${ }^{2}$ Department of Biotechnology, Bangladesh Agricultural University, Mymensingh- \\ 2202, Bangladesh and ${ }^{3}$ Farm Division, BARI, Gazipur, Email: kbdshaheen78@yahoo.com
}

\begin{abstract}
The experiment was carried out during the period from July 2008 to March, 2009 at the Biotechnology Laboratory, Department of Biotechnology, Bangladesh Agricultural University, Mymensingh. The present investigation was to be better source for shoot multiplication. The calli derived from leaf discs were cultured on shoot induction media containing different combinations and concentrations of BAP $(1.0,1.5,3.0$ and $6.0 \mathrm{mg} / \mathrm{L})$ and $\mathrm{Kn}(0.5,1.0,1.5$ and $2.0 \mathrm{mg} / \mathrm{L})$. The highest percentage of shoot regeneration $(91.66 \%)$ and the highest shoot length was $4.24(\mathrm{~cm})$ with a minimum number of days (13.33) was observed in the MS medium supplemented with $3.0 \mathrm{mg} / \mathrm{L}$ BAP and $0.5 \mathrm{mg} / \mathrm{L}$ $\mathrm{Kn}$. Thus shoot multiplication in successive subculture was possible. The present investigation was carried out to study the in vitro shoot multiplication in gladiolus by using leaf disc as explants
\end{abstract}

Keyword: Shoot proliferation, Micropropagation, BAP: 6-benzylamino purine, Kn: Kinetin, Leaf disc

\section{Introduction}

Gladiolus perennates by underground stems or corms, the infection by soil-borne fungus, Fusarium oxysporum f. sp. gladioli causing severe loss and damage is a major bottleneck to its mass propagation. With the growing symbiosis between plant breeders and biotechnologists, disease resistant varieties of Gladiolus developed through plant transformation will be a reality in near future and some reports are already available (Kamo, 1997; Kamo and Blowers, 1999; Loffler et al., 2000). It propagates either by seeds, corm formation or by Cormel differentiation. Although, seeds are an effective means of Gladiolus propagation but seed-raised plants may not produce true-to-type population (Hussain et al., 2001). Moreover, it takes four seasons for blooming. The propagation by corm and cormel formation is another conventional method of multiplication but it may transmit several viral, fungal and bacterial diseases e.g., Fusarium corm rot, Botrytis blight, bacterial leaf rot etc., thus causing a heavy loss.

Plant tissue culture offers a potential to deliver large quantities of disease-free, true-to-type healthy stock within a short span of time (Hussain et al., 2001). The In vitro multiplication of Gladiolus has been achieved by using axillary buds (Boonvanno and Kanchanapoom, 2000; Begum and Haddiuzzaman, 1995), shoot tip (Hussain et al., 2001), cormels (Nagaraju and Parthasarathy, 1995) and inflorescence axes (Ziv and Lilien-Kipnis, 2000). Moreover, successful protocols for in vitro corm formation (Dantu and Bhojwani, 1995; Sen and Sen, 1995 and Al-Juboory et al., 1997), organogenesis and somatic embryogenesis (Remotti and Toffler, 1995; Kumar et al., 2002) have also been achieved. However, in Gladiolus there is a clear scope for further refinement through In vitro culture methodology to acquire a higher number of shoots to complement traditional nursery methods (Hussain et al., 2001). Based on the above information, the present study was undertaken within the following objectives-

- To determine a suitable hormone combination shoot regeneration and plantlet establishment; and

- To develop protocol for in vitro plantlet regeneration of Gladiolus

\section{Materials and Methods}

The experiment was carried out during the period from July 2008 to March, 2009 at the Biotechnology Laboratory, Department of Biotechnology, Bangladesh Agricultural University, Mymensingh. The planting materials (bulbs) of Gladiolus from four varieties ware collected from Germplasm Center, Bangladesh Agricultural Research Institute. The Bulbs were used to germinate plants in vitro condition and after three weeks, the leaves were used as explants. MS (Murashige and Skoog, 1962) medium supplemented with different phytohormones as treatments was used in culture medium for shoot induction, shoot multiplication and maintenance and regeneration of roots from multiplied shoot. The hormones were 
added separately to MS media. For the preparation of media, stock solutions were prepared at the beginning and stored at $4 \pm 1^{\circ} \mathrm{C}$. The media were prepared from the stock solutions. The leaf derived calli were cultured on MS medium supplemented with combinations of various concentrations of BAP (1.0, 1.5, 3.0 and $6.0 \mathrm{mg} / \mathrm{l})$ and $\mathrm{Kn}(0.5,1.0,1.5$ and $2.0 \mathrm{mg} / \mathrm{L})$ for shoot initiation.

For the purpose of hardening and acclimatization to the field conditions, 10 plants (8-10 weeks old) were taken out of the culture vessels. The roots of the plantlets were thoroughly washed with tap water in order to remove even the traces of the nutrient medium. The plantlets were then transferred to the pots containing presterilized sand. The pots were kept in the culture room for two weeks; adequate water was given to the plantlets at an interval of two-to three days. After two weeks, the plants were shifted to the soil in pots and kept in the growth room. After further hardening of two weeks, the plants were shifted to the normal growth conditions of the field.

In this study, an efficient and reproducible protocol for the plantlet regeneration from leaf discs explants in Gladiolus was developed. This protocol has the potential for the in vitro regeneration of Gladiolus.

\section{Results and Discussion}

For shoot regeneration, leaf derived calli were cultured on shoot induction media containing different combined concentrations of BAP and $\mathrm{Kn}$. The basal most portions of the innermost leaves used in the present study were the most responsive to adventitious multiple shoot bud formation. Histological observation revealed direct organogenesis and nature of response (Fig. 1). Indirect mode of shoot organogenesis,, via callusing through is in literature (Sinha and Roy, 2002; Kumar et al., 1999) but the direct one as observed in the present study is definitely of advantage in case on maintaining clonal purity. The results on the effect of different concentrations of BAP and $\mathrm{Kn}$ for shoot initiation have been discussed bellow:

\section{Days required for shoot initiation}

Main effect of BAP (mg/L): Cultured explants were carefully observed in regular basis for days required for shoot regeneration. The growth regulator concentrations significantly affected the days to shoot initiation. Table 1 show that 3.0 BAP was the best and needed least number of days for shooting. Maximum numbers of days (21.66 days) were required in the medium containing $6.0 \mathrm{mg} / \mathrm{l} \mathrm{BAP}$. Hussain et al., (2001) studied shoot multiplication of two varieties (White and pink) of gladiolus. They reported the maximum number of shoots from shoot tip explants at a much higher BAP concentrations $\left(3.0 \mathrm{mgL}^{-1}\right.$ and $4.0 \mathrm{mgL}^{-1}$ for the two varieties). They suggested the higher dose requirement of BAP would be genotypedependent. But Anandhi and Seker (2000) reported that the kinetin (4.0 mg/liter) without addition of auxin was found to be effective in hastening the time taken for direct organogenesis (12 days compared to BAP).

Main effect of $\mathbf{K n}(\mathbf{m g} / \mathbf{l})$ : Cultured explants were carefully observed in regular basis for data collection on days required for shoot regeneration. The growth regulator concentrations significantly affected the days required for shoot initiation. Table 2 shows that $1.0 \mathrm{Kn}$ was the best and needed the least number of days (18 Days) for shooting. Maximum numbers of days (19 Days) were required in the $2.0 \mathrm{mg} / \mathrm{L} \mathrm{Kn}$.

Combined effect of different concentration of BAP and $\mathrm{Kn}$ : The Combined effect of different concentration of BAP and $\mathrm{Kn}$ were significantly affected the days for shoot initiation. Table 3 shows that combined effect of 3.0 BAP and $0.5 \mathrm{Kn}$ was better and needed the least number of days for shooting. Maximum numbers of days (23 days) were required in the $6.0 \mathrm{mg} / \mathrm{L}$ BAP and $2.0 \mathrm{mg} / \mathrm{L} \mathrm{Kn}$.

\section{Percentage of explants induced shoot}

Main effect of BAP (mg/L): The highest percentage of shoot initiation was (78.67\%) observed with the supplementation with 3.0 BAP within a minimum number of days (16 days) were required. Faheem Aftab et al., (2008) reported shoot induction was possible with a maximum rate (80\%) at $1 \mathrm{mg} / \mathrm{l}$ BAP by using meristem explants. The results therefore, nearly corroborate the findings of Nagaraju and Parthasarathy (1995). The lowest percentages of shoot were (26.53\%) observed in the addition of medium without BAP (Table 1) within a minimum number of days (16) were required. 
Table 1. Main effect of different concentrations of BAP on percent shoot proliferation, days required for shoot initiation and length of shoot $(\mathrm{cm})$ of variety $\mathrm{cv}$. GL4

\begin{tabular}{|l|c|c|c|}
\hline BAP $(\mathrm{mg} / \mathrm{l})$ & $\begin{array}{c}\text { Percent shoot } \\
\text { regeneration }\end{array}$ & $\begin{array}{c}\text { Days required for } \\
\text { shoot initiation }\end{array}$ & Length of shoot $(\mathrm{cm})$ \\
\hline 0 & $26.53 \mathrm{~d}$ & 16.46 & $0.78 \mathrm{c}$ \\
\hline 1.0 & $49.33 \mathrm{c}$ & 18.13 & $2.53 \mathrm{~b}$ \\
\hline 1.5 & $61.40 \mathrm{~b}$ & 18.46 & $2.46 \mathrm{~b}$ \\
\hline 3.0 & $78.06 \mathrm{a}$ & 15.73 & $3.64 \mathrm{a}$ \\
\hline 6.0 & $31.80 \mathrm{~d}$ & 21.66 & $0.96 \mathrm{c}$ \\
\hline LSD $(0.05)$ & 3.05 & 0.597 & 0.35 \\
\hline CV $(\%)$ & 6.11 & 3.25 & 17.07 \\
\hline
\end{tabular}

Figure(s) within the same column bearing different letters are significantly different at $5 \%$ level according to DMRT

Main effect of $\mathrm{Kn}(\mathrm{mg} / \mathrm{L})$ : The highest percentage of shoot initiation was (55.33\%) observed with the supplementation with $1.5 \mathrm{mg} / \mathrm{L} \mathrm{Kn}$ within a minimum days was 18 and the lowest percentage of shoot was $(35.80 \%)$ observed in the addition of medium without $\mathrm{Kn}$ (Table 2$)$ within a minimum days was 15.80. Anandhi and Sekar (2000) reported that the maximum (60\%) response was obtained from shoot tip in the concentration of kinetin $(4.0 \mathrm{mg} / \mathrm{l})$ without addition of auxin. This does in agreement with the findings of Rao et al., 1991.

Table 2. Main effect of different concentration of kinetin on percent shoot proliferation, days required for shoot initiation and length of shoot $(\mathrm{cm})$ of variety cv. GL4

\begin{tabular}{|l|c|c|c|}
\hline Kn $(\mathrm{mg} / \mathrm{l})$ & Percent shoot proliferation & $\begin{array}{c}\text { Days required for } \\
\text { shoot initiation }\end{array}$ & Length of shoot $(\mathrm{cm})$ \\
\hline 0 & $35.80 \mathrm{c}$ & 15.80 & $1.76 \mathrm{~b}$ \\
\hline 0.5 & $47.26 \mathrm{~b}$ & 18.60 & $2.10 \mathrm{ab}$ \\
\hline 1.0 & $53.46 \mathrm{a}$ & 18.00 & $1.96 \mathrm{a}$ \\
\hline 1.5 & $55.33 \mathrm{a}$ & 18.73 & $2.10 \mathrm{ab}$ \\
\hline 2.0 & $55.26 \mathrm{a}$ & 19.33 & $2.45 \mathrm{a}$ \\
\hline LSD $(0.05)$ & 3.05 & 0.59 & 0.35 \\
\hline CV $(\%)$ & 6.11 & 3.25 & 17.07 \\
\hline
\end{tabular}

Figure(s) within the same column bearing different letters are significantly different at $5 \%$ level according to DMRT

Combined effect of different concentrations of BAP and $\mathrm{Kn}$ : The highest percentage of shoot initiation was (91.67\%) observed with the combined supplementation with concentration of $3.0 \mathrm{mg} / \mathrm{L}$ BAP and $0.5 \mathrm{mg} / \mathrm{L} \quad \mathrm{Kn}$ within a minimum days were required (13days) and the lowest percentage of shoot was $(17.67 \%)$ observed in the addition of $6.0 \mathrm{mg} / \mathrm{l} \mathrm{BAP}$ and $2.0 \mathrm{mg} / \mathrm{L} \mathrm{Kn}$ (Table 3).

\section{Length of shoot}

Main effect BAP $(\mathrm{mg} / \mathrm{L})$ : The concentration of 3.0 BAP was resulted the longest shoot $(3.65 \mathrm{~cm})$ and the shortest shoot was $0.79 \mathrm{~cm}$ was observed in medium without BAP (Table 1). Anandhi and Sekar (2000) reported that BAP $4.0(\mathrm{mg} / \mathrm{l})$ was obtained $2.5 \mathrm{~cm}$ length of shoot.

Main effect $\mathrm{Kn}(\mathrm{mg} / \mathrm{L})$ : The concentration of $1.0 \mathrm{mg} / \mathrm{L} \mathrm{Kn}$ resulted the longest shoot $(1.93 \mathrm{~cm})$ and the shortest shoot $(1.767 \mathrm{~cm}$ ) was observed with supplementation of $0.5 \mathrm{mg} / \mathrm{Kn}$ (Table 2). Anandhi and Sekar (2000) reported that shoot length was $3.0 \mathrm{~cm}$ in kiniten $(4.0 \mathrm{mg} / \mathrm{L})$.

Combined effect of different concentrations of BAP and $\mathrm{Kn}$ : The concentration of $3.0 \mathrm{BAP}$ and 0.50 $\mathrm{mg} / \mathrm{L} \mathrm{Kn}$ resulted the longest shoot $(4.24 \mathrm{~cm})$ and the shortest shoot $(0.56 \mathrm{~cm})$ was observed medium without of BAP and $0.5 \mathrm{mg} / \mathrm{L} \mathrm{Kn}$ (Table 3). In order to increase the number of shoots per culture vessel, the explants were subcultured on the same medium after a regular interval of 28- 30 days. The calli initiated on different media were also maintained by sub culturing in the same way. 


\section{Conclusion}

Studies were conducted with gladiolus in order to standardize the protocol for shoot proliferation in vitro. Shoot multiplication of Gladiolus grandiflorus was studied by using leaf disc as explants and achieved maximum shoot multiplication on MS Medium containing $3.0 \mathrm{mg} / \mathrm{L}$ BAP and $0.5 \mathrm{mg} / \mathrm{L} \mathrm{Kn}$. Although it was difficult to quantify but we have observed that shoots obtained from leaf disc explants generally healthier (better vigour). So the leaf discs are a good source tissue for this purpose.

Table 3. Combined effect of different concentrations of BAP and $\mathrm{Kn}$ on percent shoot proliferation, days required for shoot initiation and length of shoot $(\mathrm{cm})$ of variety $\mathrm{cv}$. GL4

\begin{tabular}{|c|c|c|c|c|}
\hline $\begin{array}{c}\text { BAP } \\
(\mathrm{mg} / \mathrm{l})\end{array}$ & $\begin{array}{l}\text { Kinetin } \\
(\mathrm{mg} / \mathrm{l})\end{array}$ & $\begin{array}{c}\text { Percent shoot } \\
\text { proliferation }\end{array}$ & $\begin{array}{c}\text { Days required for } \\
\text { shoot initiation }\end{array}$ & $\begin{array}{l}\text { Length of shoot } \\
(\mathrm{cm})\end{array}$ \\
\hline \multirow[t]{5}{*}{0} & 0 & $0.00 p$ & 0.00 & $0.00 \mathrm{k}$ \\
\hline & 0.5 & 18.000 & 23.00 & $0.56 \mathrm{jk}$ \\
\hline & 1.0 & $26.66 n$ & 20.33 & $0.83 \mathrm{j}$ \\
\hline & 1.5 & $38.00 \mathrm{jkl}$ & 19.66 & $0.90 \mathrm{j}$ \\
\hline & 2.0 & $50.00 \mathrm{i}$ & 19.33 & $1.63 \mathrm{gh}$ \\
\hline \multirow[t]{5}{*}{1.0} & 0 & 19.000 & 21.66 & $1.73 \mathrm{gh}$ \\
\hline & 0.5 & $27.33 \mathrm{mn}$ & 18.66 & $1.82 \mathrm{gh}$ \\
\hline & 1.0 & $59.66 \mathrm{gh}$ & 17.33 & $2.13 \mathrm{efg}$ \\
\hline & 1.5 & 65.66 ef & 16.66 & 2.23defg \\
\hline & 2.0 & $75.00 \mathrm{~cd}$ & 16.33 & $4.37 \mathrm{a}$ \\
\hline \multirow[t]{5}{*}{1.5} & 0 & $42.00 \mathrm{jk}$ & 19.66 & $2.12 \mathrm{efg}$ \\
\hline & 0.5 & $56.00 \mathrm{~h}$ & 17.66 & $2.92 \mathrm{c}$ \\
\hline & 1.0 & $65.00 \mathrm{fg}$ & 17.33 & $1.92 \mathrm{fg}$ \\
\hline & 1.5 & $73.33 \mathrm{~cd}$ & 18.33 & $2.84 \mathrm{~cd}$ \\
\hline & 2.0 & $70.66 \mathrm{de}$ & 19.33 & 2.52 cdef \\
\hline \multirow[t]{5}{*}{3.0} & 0 & $85.33 \mathrm{~b}$ & 16.33 & $3.73 \mathrm{~b}$ \\
\hline & 0.5 & $91.66 \mathrm{a}$ & 13.33 & $4.24 \mathrm{a}$ \\
\hline & 1.0 & $78.33 \mathrm{c}$ & 14.33 & $3.92 \mathrm{~b}$ \\
\hline & 1.5 & $72.00 \mathrm{~d}$ & 16.33 & $3.60 \mathrm{~b}$ \\
\hline & 2.0 & $63.00 \mathrm{fg}$ & 18.33 & 2.72 cde \\
\hline \multirow[t]{5}{*}{6.0} & 0 & $32.66 \mathrm{Im}$ & 21.33 & $1.23 \mathrm{hi}$ \\
\hline & 0.5 & $43.33 \mathrm{j}$ & 20.33 & $1.00 \mathrm{hij}$ \\
\hline & 1.0 & $37.66 \mathrm{kl}$ & 20.66 & $1.00 \mathrm{ij}$ \\
\hline & 1.5 & $27.66 \mathrm{mn}$ & 22.66 & $0.95 \mathrm{ij}$ \\
\hline & 2.0 & 17.660 & 23.33 & $0.65 \mathrm{j}$ \\
\hline \multicolumn{2}{|l|}{ LSD(0.05) } & 5.22 & 1.020 & 0.61 \\
\hline \multicolumn{2}{|l|}{ CV (\%) } & 3.25 & 17.07 & 17.07 \\
\hline
\end{tabular}

Figure(s) within the same column bearing different letters are significantly different at 5\% level according to DMRT 


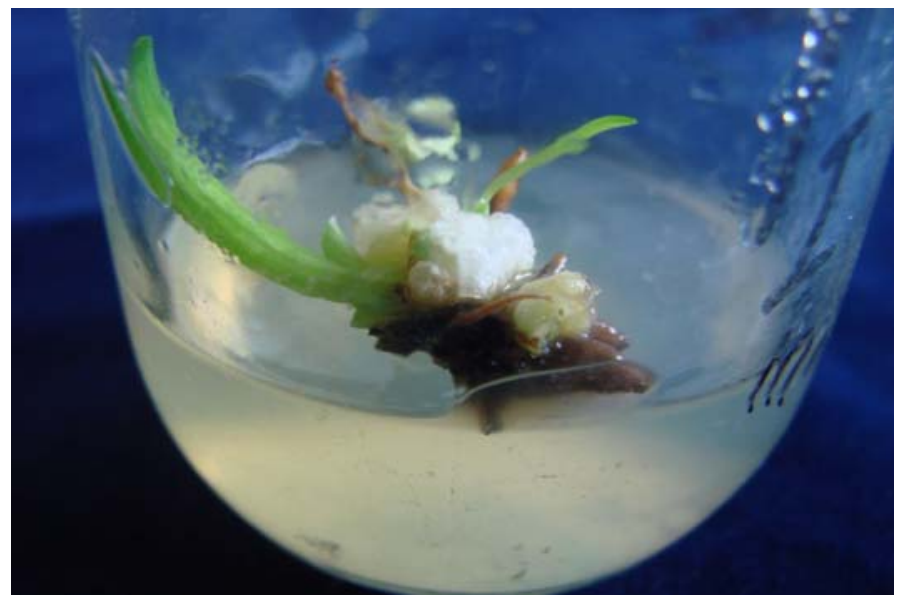

Plate 1. Multiple shoots from leaf derived calli in MS medium supplemented with $3.0 \mathrm{mg} / \mathrm{L}$

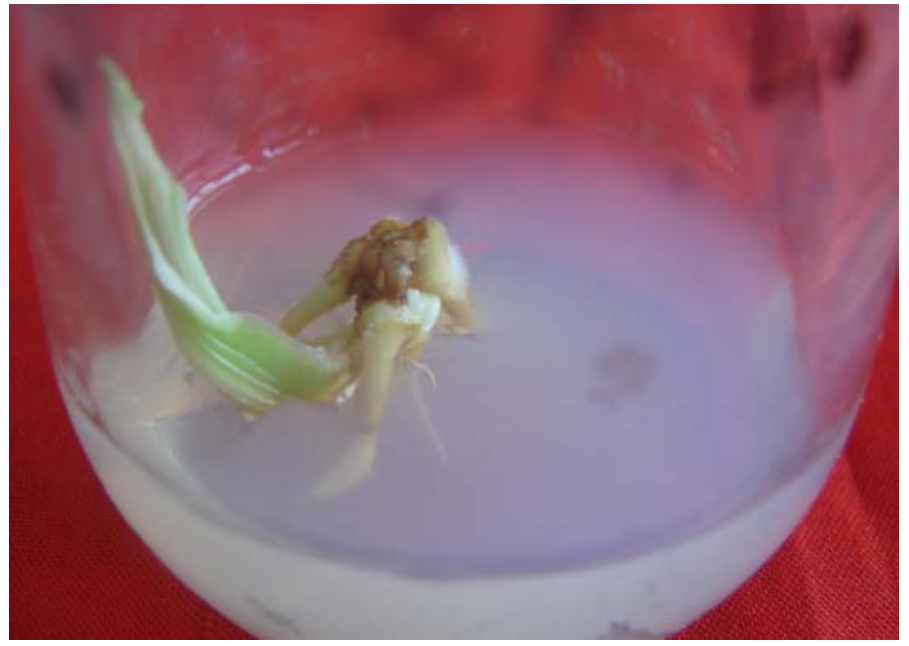

Plate 2. Multiple shoots from leaf derived calli in MS medium supplemented with $1.5 \mathrm{mg} / \mathrm{L}$ BAP and 1.0 $\mathrm{mg} / \mathrm{L} \mathrm{Kn}$

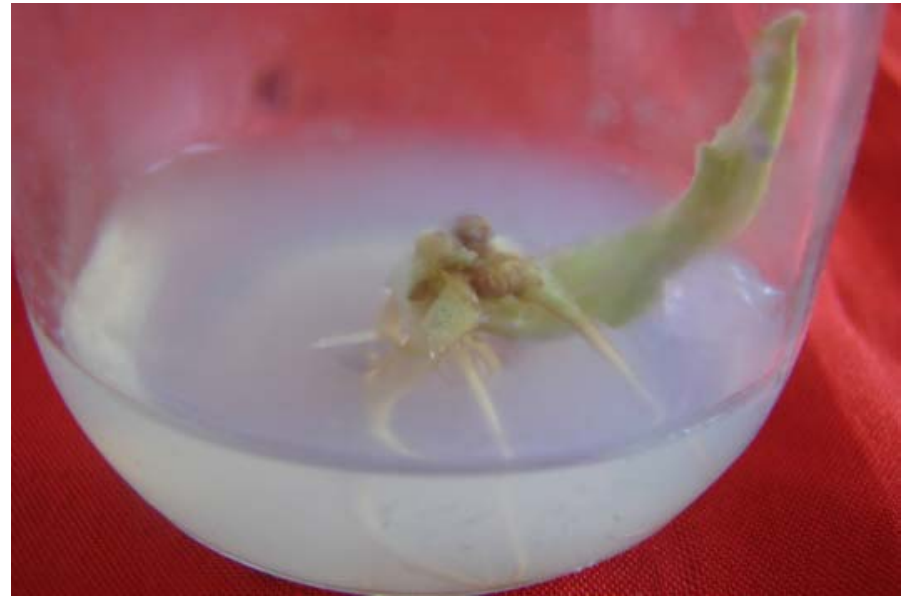

Plate 3. Multiple shoots from leaf derived calli in MS medium supplemented with $6.0 \mathrm{mg} / \mathrm{L}$ BAP and 0.5 $\mathrm{mg} / \mathrm{L} \mathrm{Kn}$ 


\section{Reference}

Aftab, F., Alam, M. and Afrasiab, H. 2008. In vitro shoot multiplication and callus induction in Gladiolus Hybridus Hort.Pak.J.Bot., 40 (2):517-522.

Al-Juboory, K.H., Shibli, R.A. and Skiryn, R. 1997.Organogenesis and Cormel production from callus culture of Gladiolus cv. Balady. Murtha J. Res. Stud., 12: 143-160.

Anandhi, S. and Sekar, K. 2000. Studies on In vitro plantlet production in Gladiolus cv. Friendship.Indian J. Hort., 4:360-363.

Begum, S. and Haddiuzaman, S. 1995. In vitro rapid shoot proliferation and corm development in Gladiolus grandiflorus cv. Red brand. Plant Tiss. Cult., 5: 7-12.

Boonvanno, K. and Kanchanapoom, K. 2000. In vitro propagation of Gladiolus.Suranaree J. Sci. Technol., 7: 25-29.

Dantu, P.K. and Bhojwani, S. S. 1995. In vitro corm formation and field evaluation of corm-derived plants of Gladiolus. Sci. Hort., 61: 115-129.

Hussain, I., Muhammad, A., Rashid, H. and Quraishi, A. 2001. In vitro multiplication of Gladiolus. Plant Tiss. Cult., 11:121-126

Kamo, K. 1997. Effect of phytohormones on plant regeneration form callus of Gladiolus Cultivar 'Jenny Lee". In vitro Cell Dev. Biol., 30: 265-271.

Kamo, K. and Blowers, A. 1999. Tissue specificity and expression level of gusA under rolD Mann opine syntheses and translation elongation factor 1 subunit a promoters in transgenic Gladiolus plants. Plant Cell Rep., 18: 809-815.

Kumar, A., Palni, L. M.S., Sood, A., Sharma, M., Palni , U.T. and Gupta, A.K. 2002. Heat-shock induced somatic embryogenesis in callus cultures of Gladiolus in the presence of high sucrose. J. Hort. Sci. Biotech., 77: 73-78.

Kumar, A., Sood, A., Palni, L.M.S. and. Gupta, A.K. 1999. In vitro propagation of Gladiolus hybrids Hort: Synergistic effect of heat shock and sucrose on morphogenesis-Micropropagation of Gladiolus. Plant Cell Tiss. Org. Cult., 57(2): 105-112.

Loffler, H.J.M., Mouris J.R., Van harmelen, M.J. and Van Tuyl, J.M.. 2000. Transformation of gladioli for Gusarium resistance. ISHS Acta Hort. 508: XIX International Symposium on Improvement of Ornamental Plants.

Murashige, T. and Skoog, F. 1962. A revised medium for rapid growth and bioassay with Tobacco tissue culture. Physiol. Plant. 15:472-497.

Nagaraju, V. and Parthasarith, V.A. 1995. Effect of growth regulators on in vitro shoots of Gladiolus hybridus. Folia Hort., 7: 93100.

Rao, T.M., Negi, S.S. and.Swamy, R.D. 1991. Micropropagation of Gladiolus. Indian J. Hort., 48:139-145.

Remotti, P.C. and Toffler, H.J.M. 1995. Callus induction and plant regeneration form Gladiolus. Plants Cell Tiss. Org. Cult., 42(2): 171-178.

Sen, J. and Sen, S. 1995. Two-step bud culture technique for a high frequency regeneration of Gladiolus corms. Sci. Hort., 64(1-2): 133-138.

Sinha, P and Roy, S.K. 2002. Plant regeneration through in vitro cormel formation from callus culture of Gladiolus primulinus Baker. Plant Tiss. Cult.12:139-145.

Ziv, M. and Lilien-Kipnis, H.L. 2000. Bud regeneration from inflorescence explants for rapid propagation of geophytes in vitro. Plant Cell Rep., 19: 845-850. 